\title{
PENGARUH TINGGI MEDIA PASIR SILIKA TERHADAP PENYISIHAN KEKERUHAN PADA UNIT FILTRASI PENGOLAHAN AIR MINUM
}

\author{
Fathimah Hanun Syifaul Jannah \\ Jurusan Teknik Lingkungan, Fakultas Arsitektur Lanskap dan Teknologi Lingkungan, \\ Universitas Trisakti, Jakarta, Indonesia
}

Email korespondensi: fathimah08215024@std.trisakti.ac.id

\begin{abstract}
ABSTRAK
Seiring dengan peningkatan jumlah penduduk dan kegiatannya yang mengakibatkan meningkatnya kebutuhan terhadap air bersih. Maka, diperlukan pengolahan air ini bertujuan untuk menghasilkan air minum yang berkualitas mengacu pada standar air minum Indonesia yaitu PerMenkes No. 492 tahun 2010 tentang Persyaratan Kualitas Air Minum. Pada karya ilmiah ini akan dibahas unit media pasir silika yang merupakan unit pengolahan air yang sangat penting dalam menyisihkan kekeruhan. Nilai parameter kekeruhan pada kualitas air menandakan bahwa terdapat senyawa organik maupun anorganik yang berada di dalam air sehingga dapat mengurangi nilai estetika dari air minum. Tujuan dari karya ilmiah ini adalah untuk mengetahui tinggi media pasir silika yang paling unggul dalam menurunkan nilai kekeruhan pada kualitas air minum. Pada unit filtrasi ketinggian media filter sangat berpengaruh pada penyisihan kekeruhan dan headloss. Semakin tingggi media filter maka penyisihan kekeruhan akan semakin baik namun headloss yang dihasilkan akan semakin besar. Pada karya ilmiah ini membandingkan tinggi media pasir silika dari hasil penelitian terdahulu dengan tinggi media berkisar antara 20-100 $\mathrm{cm}$. Tinggi yang sangat optimal dalam penyisihan kekeruhan adalah media pasir silika dengan tinggi media $100 \mathrm{~cm}$ dengan efisiensi penyishan $81 \%$.
\end{abstract}

Kata Kunci: pasir silika, tinggi media, kekeruhan

\section{PENDAHULUAN}

Air minum sangat dibutuhkan bagi manusia dan harus tersedia karena tanpa air, manusia tidak dapat melangsungkan kehidupannya. Seiring dengan pertambahan jumlah penduduk sehingga kebutuhan air bersih meningkat untuk memenuhi kebutuhan hidup. Maka, diperlukan pengolahan air ini bertujuan untuk menghasilkan air minum yang berkualitas mengacu pada standar air minum Indonesia yaitu PerMenkes No. 492 tahun 2010 tentang Persyaratan Kualitas Air Minum. Pelayanan air minum yang melihat kualitas air dan kuantitas air sendiri dilakukan untuk meningkatkan derajat kesehatan dan kualitas kehidupan masyarakat. Salah satu dari unit pengolahan air minum yang paling penting adalah media pasir silika, yang berfingsi untuk mengurangi kekeruhan yang diakibatkan dari terlarutnya senyawa organik maupun anorganik dengan cara menyisihkan partikelpartikel tersuspensi yang sangat halus yang dapat mengurangi nilai estetika kualitas air minum.

\section{TINJAUAN PUSTAKA \\ Kualitas Air}

Menurut Evan Fabian, dkk, (2018) air bersih adalah sumber utama untuk kesehatan dan kesejahteraan masyarakat yang semakin sulit diperoleh, ketersediaan air semakin menurun seiiring dengan meningkatnya jumlah permintaan air. Ditambah dengan kualitas air yang menurun merupakan penyebab utama sulitnya mendapatkan air bersih. Dalam mengolah air baku menjadi air bersih pemerintah mengeluarkan peraturan berupa persyaratan kualitas air baku yang tercantum dalam peraturan Pemerintah Nomor 82 Tahun 2001. Sementara untuk kualitas air yang akan dikonsumsi harus memenuhi 
persyaratan kesehatan, maka pemerintah dalam hal ini menteri kesehatan mengeluarkan peraturan mengenai persyaratan kualitas air minum seperti yang tercantum dalam Peraturan Menteri Kesehatan Nomor 492 Tahun 2010.

\section{Proses Pengolahan Air}

Menurut Kawamura, (2000) pengolahan yang menggunakan prosese koagulasi, flokulasi, sedimentasi, filtrasi, dan desinfeksi, dilengkapi dengan memantau proses dan pemeriksaan instrumen pengukuran, sehingga menghasilkan air yang layak dikonsumsi masyarakat bagaimanapun kondisi cuacanya dan lingkungannya. Bangunan IPA harus mempertimbangkan desain bangunan yang sederhana, efektif, dapat diandalkan, tahan lama, dan murah dalam pembiayaan pemeliharaan dan pembangunan untuk mendapatkan kualitas air pengolahan yang diinginkan.

\section{Pengolahan Fisik}

Proses pengolahan air yang bertujuan untuk mengurangi dan atau menghilangkan padatan kasar yang terbawa oleh air baku sehingga tidak menggangu proses pengolahan selanjutnya.

\section{Pengolahan Kimia}

Untuk memenuhi kualitas yang diinginkan, maka dilakukan penambahan bahan kimia tertentu dalam proses pengolahan air bersih. Penambahan bahan kimia tersebut berupa:

1. Koagulan

Koagulan adalah zat kimia yang dibutuhkan pada proses pengolahan air minum untuk membentuk flok-flok dari partikel-partikel tersuspensi dan koloid. Sehingga diharapkan dapat mengurangi kekeruhan karena adanya partikel koloid organik dan anorganik, mengurai bau, rasa, dan warna yang disebabkan oleh partikel koloid dalam air baku. Koagulan terdiri dari Alumunium sulfat $\left(\mathrm{Al}_{2} \mathrm{SO}_{4}\right)$, Feri chloride $\left(\mathrm{FeCl}_{3}\right)$, Fero chloride $\left(\mathrm{FeCl}_{2}\right)$, Feri sulfat $\left(\mathrm{Fe}_{2}\left(\mathrm{SO}_{4}\right)_{3}\right)$, danChitosan, Curie flock, Poly Alumunium Chloride (PAC) $\left(\mathrm{Al}_{10}(\mathrm{OH})_{15} \mathrm{Cl}_{15}\right)$.

2. Pembubuhan kapur

Pembubuhan kapur diperlukan bila air baku yang diolah memiliki kadar alkalinitas rendah. Pembubuhan ini bertujuan untuk menetralkan $\mathrm{pH}$, karena pada umumnya $\mathrm{pH}$ akan turun setelah pembubuhan koagulan yang bersifat asam.

3. Desinfektan

Untuk mematikan virus dan bakteri pembawa penyakit, juga menekan pertumbuhan algae (lumut) agar menjaga nilai estetika. Maka, diperlukan pemberian desinfektan.

\section{Pengolahan Biologis}

Yaitu suatu pengolahan secara biologis untuk mengilangkan bakteri-bakteri yang masih terkandung dalam air.

\section{Filtrasi}

Filtrasi adalah proses pemisahan padatan dari larutan untuk menyisihkan partikelpartikel tersuspensi yang sangat halus di mana larutan tersebut dilewatkan melalui suatu media berpori atau materi berpori. Proses ini digunakan pada instalasi pengolahan air minum untuk menyaring air yang telah dikoagulasi dan diendapkan untuk menghasilkan air minum dengan kualitas yang baik (Djoko M.Hartono (20010)). 
Filtrasi memiliki dua jenis metode pengolahan yaitu, filtasi pasir cepat (rapid sand filter) dan filtrasi pasir cepat (slow sand filter). Rapid sand filter merupakan penyaringan degnan kecepatan penyaringan relatif lebih besar dibandingan dengan slow sand filter.

Menurut Duran, dkk (2009), ketinggian media filter sangat berpengaruh pada penyisihan kekeruhan dan headloss. Semakin tinggi media filter maka penyisihan kekeruhan akan semakin baik namun headloss yang dihasilkan akan semakin besar. Hal ini dikarenakan semakin tinggi media filter maka semakin banyak ruang kosong antar partikel sehingga partikel yang terjebak dalam media filter akan semakin banyak dan penyisihan semakin baik.

Pada unit filtrasi media yang dapat mengurangi kadar kekeruhan adalah pasir silika. Pasir ini sangat berbeda dengan pasir pada umumnya. Media filter air yang satu ini dapat digunakan secara efektif dalam melakukan penyaringan air. Selan menyaring air pasir, silika dapat memisahkan air dan lumpur serta partikel-partikel lainya yang terdapat di dalam air. Untuk mengetahui tinggi media pasir silika yang paling efektif dalam mengurangi kekeruhan, maka dilakukan perbandingan dari beberapa hasil penelitian terdahulu mengenai penggunaan tinggi media pasir silika dapat dilihat pada Tabel 1.

Tabel 1. Perbandingan Media Pasir Silika

\begin{tabular}{|c|c|c|}
\hline Judul Paper, Tahun & Penulis & Hasil Penelitian \\
\hline $\begin{array}{l}\text { Evaluasi Dan Optimalisasi Instalasi } \\
\text { Pengolahan Air Minum (Ipa I) } \\
\text { Sungai Sengkuang PDAM Tirta } \\
\text { Pancur Aji Kota Sanggau, } 2014\end{array}$ & Joni Hermanto, dkk & $\begin{array}{l}\text { Rapid sand filter dengan } \\
\text { menggunakan media Pasir } \\
\text { silika } 0,95 \mathrm{~m} \text { dan kerikil } 0,1 \mathrm{~m} . \\
\text { Hasil kualitas air baik }\end{array}$ \\
\hline \begin{tabular}{lrrr} 
Evaluasi & \multicolumn{2}{c}{ Kinerja } & Instalasi \\
Pengolahan Air & Minum & (Ipam) \\
Karangpilang I & PDAM & Surya \\
Sembada Kota & Surabaya & Secara \\
Kuantitatif, 2018 & &
\end{tabular} & $\begin{array}{l}\text { R. Gagak Eko Bhaskoro } \\
\text { dan Tutut Ramadhan }\end{array}$ & $\begin{array}{l}\text { Rapid sand filter dengan } \\
\text { menggunakan media } \\
\text { Pasir silika } 50 \mathrm{~m} \\
\text { Media pasir yang kurang akan } \\
\text { menyebabkan penyaringan } \\
\text { partikel menjadi berkurang. } \\
\text { Kualitas air minum baik }\end{array}$ \\
\hline 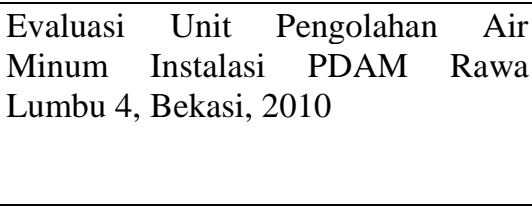 & Djoko M.Hartono, dkk & $\begin{array}{l}\text { Rapid sand filter dengan } \\
\text { menggunakan media Pasir } \\
\text { silika } 50 \mathrm{~cm} \text { dan kerikil } 20 \mathrm{~cm} \text {. } \\
\text { Media bekerja dengan optimal, } \\
\text { kualitas air minum baik }\end{array}$ \\
\hline $\begin{array}{l}\text { Perencanaan Bangunan Pengolahan } \\
\text { Air Minum di Kecamatan Bekasi } \\
\text { Timur, Kota Bekasi, Jawa Barat, } \\
2018\end{array}$ & Adrian Dwi Putra & $\begin{array}{l}\text { Rapid sand filter dengan media } \\
\text { antrasit dan pasir, kualitas air } \\
\text { untuk parameter kekeruhan } \\
\text { masih belum baik }\end{array}$ \\
\hline $\begin{array}{l}\text { Penyisihan Kekeruhan Pada Sistem } \\
\text { Pengolahan Air Sungai dengan } \\
\text { Teknologi Rapid Sand Filter }\end{array}$ & $\begin{array}{l}\text { Catur Pamularsih dan } \\
\text { Dera Choanji }\end{array}$ & $\begin{array}{l}\text { Rapid sand filter menggunakan } \\
\text { media pasir } 60 \mathrm{~cm} \text { dan } 100 \mathrm{~cm} \\
\text { dengan penghilangan } \\
\text { kekeruhan } 36 \% \text { dan } 81 \%\end{array}$ \\
\hline $\begin{array}{l}\text { Evaluation of the Impact of Filter } \\
\text { Media Depth on Filtration } \\
\text { Performance and Clogging } \\
\text { Formation of a Stormwater Sand } \\
\text { Filter, } 2016\end{array}$ & Lee Byung sik & $\begin{array}{l}\text { Media pasir silika dengan } \\
\text { tinggi } 40 \mathrm{~cm} \text { menghilangkan } \\
\text { kekeruhan } 22,73 \% \text { dan tinggi } \\
57 \mathrm{~cm} \text { menghilangkan } 16,5 \%\end{array}$ \\
\hline
\end{tabular}




\begin{tabular}{l|l|l}
\hline \multicolumn{1}{c|}{ Judul Paper, Tahun } & \multicolumn{1}{|c}{ Hasil Penelitian } \\
\hline $\begin{array}{l}\text { Assessment of Impact of Filter } \\
\text { Design Variables on Clogging in } \\
\text { Stormwater Filters }\end{array}$ & Kandra H.S & $\begin{array}{l}\text { Media pasir silika dengan } \\
\text { ketinggian } 10 \mathrm{~cm} \text { efisiensi } \\
\text { penyisishan kekeruhan 42\%, } \\
\text { ketinggian } 30 \mathrm{~cm} \text { dengan } \\
\text { efisiensi penyisihan 57\%, } \\
\text { ketinggian 50 cm dengan } \\
\text { efisiensi } 62 \% \quad\end{array}$ \\
\hline
\end{tabular}

Dari hasil analisa perbandingan Tabel 1. Didapatkan bahwa tinggi media pasir silika yang paling efektif dalam mengurangi parameter kekeruhan adalah dengan ketinggian media pasir silika sebesar $100 \mathrm{~cm}$ dengan efisiensi penyisihan kekeruhan sebesar $81 \%$.

\section{PENUTUP}

Berdasarkan perbandingan tinggi media pasir silika dalam pengolahan air minum skala besar, tinggi media yang paling optimal dalam penyisihan kekeruhan adalah media pasir silika dengan tinggi media $100 \mathrm{~cm}$, karena dapat menyisihkan kekeruhan $81 \%$.

\section{DAFTAR PUSTAKA}

Bhaskoro R. Gagak Eko, Ramadhan Tutut. 2018. Evaluasi Kinerja Instalasi Pengolahan Air Minum (IPAM) Karangpilang I PDAM Surya Sembada Kota Surabaya Secara Kuantitatif. Jurnal Presipitasi : Media Komunikasi dan Pengembangan Teknik Lingkungan.15(2). ISSN 2550-0023

Byung-Sik Lee, dkk.2016. Evaluation of the Impact of Filter Media Depth on Filtration Performance and Clogging Formation of a Stormwater Sand Filter. Journal of Korean Society on Water Environment 32(1) DOI: http://doi.org/10.15681/KSWE.2016.32.1.36

Duran-Ros, M., Puig-Barguès, J., Arbat, G., Barragȧn, J., Ramírez de Cartagena, F., 2009. Effect of Filter, Emitter and Location on Clogging When Using Effluent. Agricultural Water Management 96(10): 67-79

DOI: https://doi.org/10.1016/j.agwat.2008.06.005

Hartono Djoko M, Irma Gusniani, dan R.M. Sandyanto A.S, 2010. Evaluasi Unit Pengolahan Air Minum Instalasi PDAM Rawa Lumbu 4, Bekasi. Jurnal Purifikasi, 11(2): 119-120.

Hermanto Joni. 2014. Evaluasi Dan Optimalisasi Instalasi Pengolahan Air Minum (IPA I)

Sungai Sengkuang Pdam Tirta Pancur Aji Kota Sanggau/ Jurnal Teknologi Lingkungan Lahan Basah.1(1)

Kandra H. S. , Deletic A. , McCarthy D. 2014. Assessment of Impact of Filter Design Variables on Clogging in Stormwater Filters. Journal Water Resources Management 28(7): 1873-1885

DOI: http://doi.org/10.1007/s11269-014-0573-7

Kawamura, S. 2000. Integrated Design and Operation of Water Treatment Facilities. Canada: John Wiley dan Sons, Inc.

Pamularsih Catur, Dera Chaonji. 2013. Penyisihan Kekeruhan Pada Sistem Pengolahan Air Sungai dengan Teknologi Rapid Sand Filter. Jurnal Teknologi dan Industri 2(4): 48-54

PerMenKes. 2010. Peraturan Menteri Kesehatan Republik Indoneisa nomor 492 tahun 
2010 tentang Persyaratan Kualitas Air Minum.

Peraturan Pemerintah.2001. Peraturan Pemerintah Republik Indonesia nomor 82 tahun 2001 tentang Persyaratan Kualitas Air Baku.

Evan Fabian, Evi Afiantun. 2018. Influence Of Mixing And Detention Time In Electro Coagulation Process To Treat Raw Water At Badak Singa Water Treatment Plant. Indonesian Jurnal of Urban and Environmental Technology. 1(2): 137-150.

DOI: http://dx.doi.org/10.25105/urbanenvirotech.v1i2.2823 